\title{
Irrigation Water Potential and Land Suitability Assessment in Kurfa Chele- Girawa Watershed, Wabe Shebelle River Basin, Ethiopia
}

\author{
Girma Mideksa $^{1, a}$, Tasisa Temesgen ${ }^{1, b, *}$ \\ ${ }^{1}$ School of Natural Resource Management and Environmental Sciences, Haramaya University, Dire Dawa, Ethiopia
}

*Corresponding author

A R T I C L E I N F O
Research Article
Received : 01/08/2019
Accepted : 10/12/2019

A B S T R A C T

Assessing available water and land for irrigation are important for planning their use. In the watershed, stream flows from some of the rivers are not known and potential irrigable areas have not been identified. By delineating watershed boundary, irrigation suitability factors such as soil type, slope, land cover/use, and distance from the water supply were classified based on the FAO guideline for land evaluation in to S1, S2, S3 and N suitability classes independently. The irrigation potential suitability analysis of soil, slope, land cover/use and Euclidean distance indicates that 55.1 $\%, 95.6 \%, 88.6 \%$ and $93.7 \%$ respectively are in the range of highly to marginally suitable. By weighted overlay analysis, total surface irrigation suitability potential of the study area is $54.6 \%$,

Keywords:

Irrigable land

Land suitability

from this, the potential irrigable land obtained by multi_criteria analysis has $45.9 \%$. The total

Surface irrigation potential

Weighted overlay

Water supply

available flow above abstraction site is $335.7 \mathrm{~m}^{3} / \mathrm{s}$ or 2.9 -million-meter cube (MMC) annually.

\section{Introduction}

Ethiopia depends on rain-fed agriculture with limited use of irrigation for agricultural production. It is estimated that more than $90 \%$ of the food supply in the country comes from low productivity rain-fed smallholder agriculture and hence rainfall is the single most important determinant of food supply and the country's economy (Belete, 2006). The major problem associated with rainfall-dependent agriculture in the country is the high degree of rainfall variability and unreliability. Irrigation potential represents a combination of information on gross irrigation water requirements, an area of soils suitable for irrigation and available water resources by basin (FAO, 1997).

Ethiopia has vast cultivable land (30 to $70 \mathrm{Mha}$ ), but only about a third of that is currently cultivated (approximately $15 \mathrm{Mha}$ ), with current irrigation schemes covering about 640,000 ha across the country. However, the study estimates that total irrigable land potential in Ethiopia is 5.3 Mha assuming use of existing technologies, including 1.6 Mha through RWH and groundwater (Seleshi and Awulachew, 2010).

In Kurfa Chele-Girawa watershed, exploitation of their water resources for irrigated agriculture is low. The efforts to establish small and large-scale irrigation schemes in the watershed are constrained by a number of uncertainties.
Stream flows from some of the rivers are not known. and potential irrigable areas in the watershed have not been identified.

The main objective of this study were -

- To assess irrigation water potential for surface irrigation in study area.

- To evaluate irrigation land suitability for surface Irrigation in study area

- To develop irrigation potential map of the study area for future planning and development possibilities.

\section{Material and Method}

\section{Description of the Study Area}

The study area is found in the Kurfa Chele-Girawa watershed of Wabe Shebelle basin which is located in East Oromia Regional state covering the full areas of Kurfa Chele, $90 \%$ of Haramaya, the half parts of Girawa, Kersa and Fedis districts which is located between $41^{\circ} 42^{\prime} 3.46^{\prime \prime}$ to $42^{\circ} 3^{\prime} 12.84^{\prime \prime}$ East longitude and $8^{\circ} 43^{\prime} 3.10^{\prime \prime}$ to $9^{\circ} 25^{\prime}$ $59.1^{\prime \prime}$ North latitude as show in figure 1. The areal extent of the watershed is $2,373.6 \mathrm{~km}^{2}$ with the altitude range of 996 masl to 3173 masl. 
The mean annual precipitation range of the watershed varies from $400 \mathrm{~mm}$ to $1300 \mathrm{~mm}$. The mean minimum and maximum temperature ranges of the watershed are 18 to $31.7^{\circ} \mathrm{C}$ respectively.

The materials and data used to assess the irrigation water potential and land suitability of this study were GPS, Satellite images, Topographic maps, Soil data, DEM (Digital Elevation Model), software's such as ArcGIS10.1, ArcSWAT10.1 and ENVI 4.5).

\section{Method}

After all the necessary data were collected from different data sources, further analysis was carried out for each physical land suitability factors to evaluate suitability of the suggested land for surface irrigation. The main irrigation suitability factors undertaken during the study were slope, soil, land use/cover and water sources. The suitability of each factors were analyzed and finally weighted to get existing and potential irrigable sites.

\section{Watershed Delineation}

Watershed delineation can be done by following drainage boundaries on the DEM, masking the DEM of Kuraf-Chele Girawa watershed of Wabe-Shebelle basin. The delineation process requires a Digital Elevation Model
(DEM) in ESRI grid format and the watershed was delineated using Arc SWAT. DEM data were obtained from ILRI GIS database and was used as input data in ArcGIS to delineate watersheds and to derive slope map of the study area for irrigation suitability analysis (Winchell et al., 2008; Kebede,2010).

\section{Identification of Potential Irrigable Sites}

Once their individual suitability was assessed, the irrigation suitability factors such as slope, soil, land cover/use and distance between water supply and the potential command area are weighted overlay to get potential irrigable sites.

\section{Slope Suitability Analysis}

To derive slope suitability map of the study area, DEM of the area was clipped from SRTM of NASA satellite of 30m by 30m' resolution from EARTHEXPLORER (2019) by masking layer of the watershed using Arc GIS software. Then the slope map of the watershed was derived using the "Spatial Analysis" tool in ArcGIS. The Slope derived from the DEM was classified based on the classification system of FAO (1996) using the "Reclassification" tool, which is an attribute generalization technique in ArcGIS (Table 1).

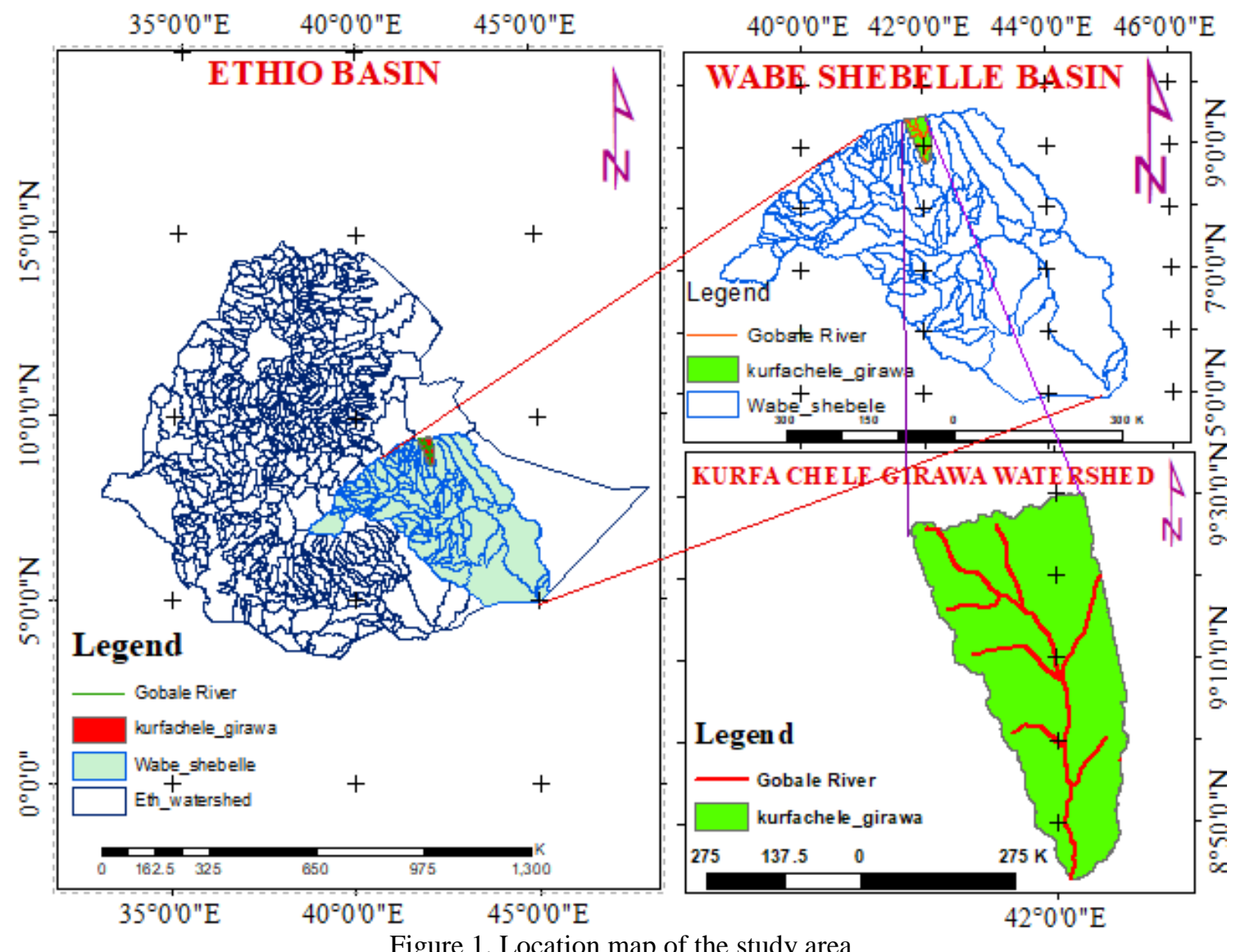

Figure 1. Location map of the study area

Table 1 . Slope suitability classification for surface irrigation*

\begin{tabular}{c|cc}
\hline Legend & Slope (\%) & Factor rating \\
\hline 1 & $0-2$ & S1 \\
2 & $2-5$ & S2 \\
3 & $5-8$ & S3 \\
4 & $>8$ & $\mathrm{~N}$ \\
\hline
\end{tabular}

*Source: FAO (1996) 
Table 2. Soil suitability factor rating*

\begin{tabular}{l|cccc}
\hline \multicolumn{1}{c}{ Factors } & \multicolumn{4}{c}{ Factor Rating } \\
\cline { 2 - 5 } & S1 & S2 & S3 & Very Poor \\
\hline Drainage class & Well & Imperfect & Poor & $<50$ \\
Soil depth $(\mathrm{cm})$ & $>100$ & $80-100$ & $50-80$ & - \\
Soil texture & L, SiCL, C & SL & - & - \\
Salinity & $<8$ mmhos/cm & $8-16$ mmhos/cm & - & - \\
Alkalinity & $<15$ ESP & $15-30$ ESP & - & \\
\hline
\end{tabular}
$<15$ ESP

*Source: FAO guideline for the land evaluation, (1976, 1979 and 1991), Loam(L), clay(C), silty clay loam(SiCL), sandy loam(SL) and Exchangeable Sodium percentage(ESP)

\section{Soil Suitability Assessment}

To assess soil suitability of the study area for irrigation was analyzed by taking soil physical and chemical properties from the OWWDSE Integrated land use planning of Wabe-Shebelle basin (2010). Soil suitability rating below was used based on the FAO guidelines for land evaluation (FAO, 1976, 1979, 1990, 1991) and FAO (1997) land and water bulletin and Kebede (2010).

The soil vector layer was converted into a raster layer using conversion tool "To Raster or Feature to Raster module". The rasterized soil map of the study area was then reclassified based on their soil type name, texture, depth and drainage class. Using overlay tool in Arc GIS 10.1 Spatial analyst, weighted overlay analysis of these factors ware performed to determine their suitability for surface irrigation (Table 2).

\section{Land Cover/Use}

The land Use/ cover classification was done using SPOT satellite image of $1.5 \mathrm{~m}$ to $5 \mathrm{~m}$ resolution for identifying land cover types to estimate potentially irrigable land. The classification was carried out using ENVI software. Sample training sites were selected and to calculate overall accuracy, user's accuracy, producer's accuracy, kappa coefficient and confusion matrix to know how many pixels in the ground truth region of interests (ROIs) were classified correctly (Jaruntorn et al., 2004 and Kebede, 2010).

\section{Distance from The Water Supply (Source)}

To identify irrigable land close to the water supply (rivers), straight-line (Euclidean) distance from watershed outlets was calculated using DEM of $30 \mathrm{~m} * 30 \mathrm{~m}$ cell size and reclassified.

\section{Selection of Potential Suitable Site for Irrigation}

The model structure for selecting the best sites for potential irrigable land was built on the basis of hierarchical structures. Hierarchical structures break down all criteria into smaller groups (or sub-models). Hierarchical structures were done according to the similarity of the elements with regard to the function they perform or the property they share (Saaty 1988). The top or first level in the hierarchy is the ultimate goal of the multi-criteria decision-making analysis process. The intermediate or second hierarchy level lists the relevant evaluation criteria that were compared pair-wise to assess their relative weights. The lowest level in the hierarchy contains the evaluation objects. Multi-criteria decision analysis requires that the values contained in the different layers be transformed into comparable units.

\section{Estimating Surface Water Resources Potential of River Catchments}

The available surface water of the catchments was estimated using stream flow discharges of the gauging stations obtained from (Ministry of Water, Irrigation and Electricity) and rainfall data (NMA). The stream flows that were used as input to determine discharges at ungauged sites were measured at the gauging stations inside the study area.

\section{Estimating Discharges at Un-Gauged Sites from Gauged Sites}

The rainfall data analysis results and discharges from gauged sites were used to estimate the stream flow at the ungauged sites in the study area. Since irrigation potential of perennial rivers was considered in this study, a long term average of stream-flow at gauged sites and mean monthly areal rainfall of the sites were used to estimate the discharges at ungauged sites. This is performed by transferring the runoff coefficient of the gauged sites to ungauged sites (FAO, 1997; Goldsmith, 2000; DFID, 2004). The estimation of monthly average runoff of the ungauged river catchments from gauged river catchments using the following equation (Jamshid,2003).

$$
\mathrm{Q} \text { ungauged }=\left(\frac{\text { A ungauged }}{\text { A gauged }}\right) \times \mathrm{Q} \text { gauged }
$$

Where;

$Q_{\text {ungauged }}=$ discharge at an ungauged site $\left(\mathrm{m}^{3} / \mathrm{s}\right)$,

$A_{\text {ungauged }}=$ drainage area of the ungauged site $\left(\mathrm{km}^{2}\right)$,

$\mathrm{Q}_{\text {gauged }}=$ discharge at the gauged site $\left(\mathrm{m}^{3} / \mathrm{s}\right)$,

$\mathrm{A}_{\text {gauged }}=$ drainage area at the gauged site $\left(\mathrm{km}^{2}\right)$.

\section{Results and Discussions}

\section{Irrigation Suitability Evaluation}

Slope suitability

The results of slope suitability show that $54.5 \%$ is highly suitable, $29.2 \%$ is moderately suitable and $11.8 \%$ is marginally suitable for surface irrigation system. The remaining $4.4 \%$ of the area of watershed is not suitable for surface irrigation. According to FAO (1976) surface irrigation suitability classification, most of the area of the watershed was falls below $8 \%$, which is suitable range of slope classification with miner modification to negotiate the natural slope.

Soil suitability

The major soil groups identified in the study area are Luvisols, Vertisols, Cambisols, Fluvisols, and Leptosols as shown in Figure 3. 


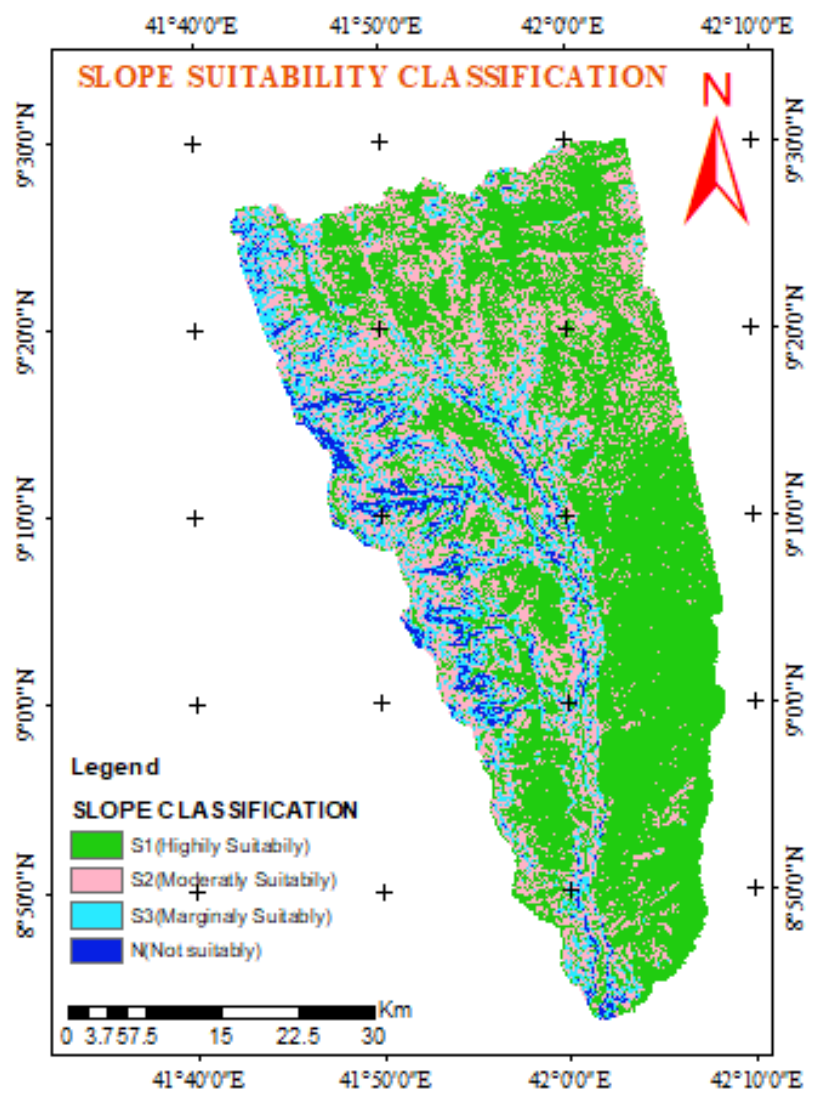

Figure 2. Slope suitability map of the study area for surface irrigation

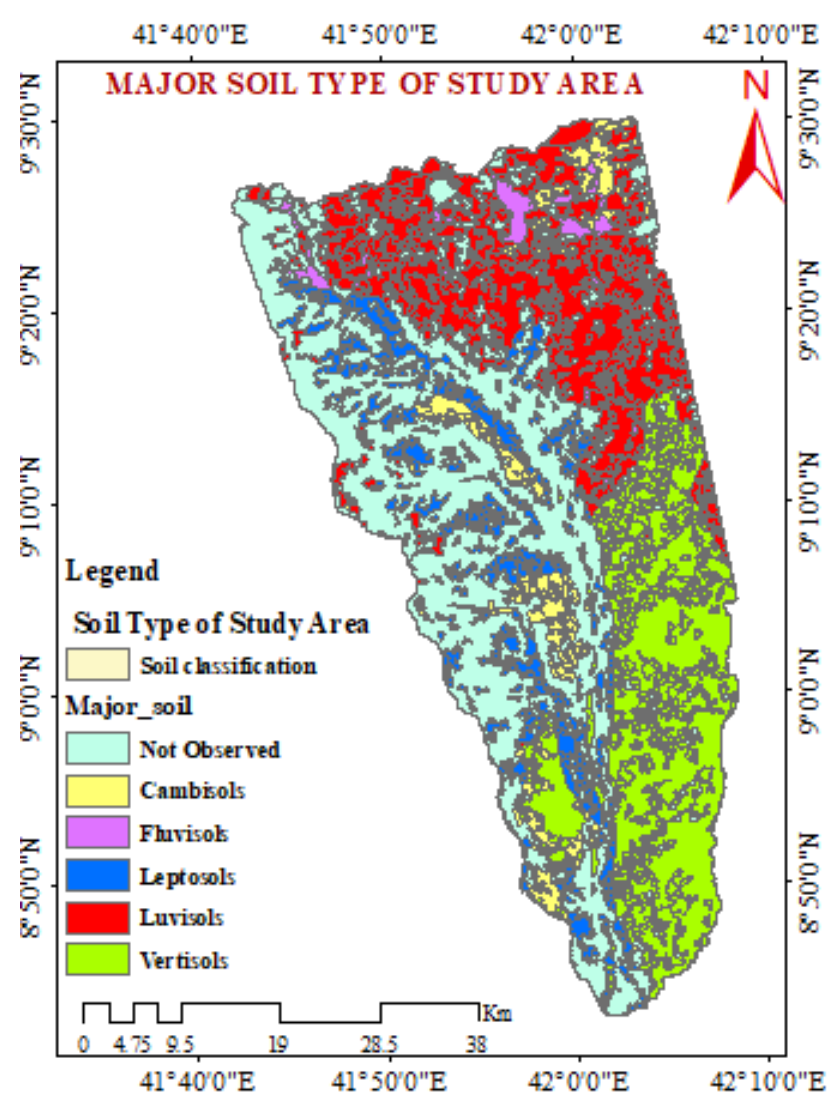

Figure 3. Soil classification of study area map

Table 3. Soil suitability classification result for surface irrigation

\begin{tabular}{|c|c|c|c|c|c|c|c|c|c|}
\hline Soil Type & Soil Map Unit & Depth & Textur & Drainage & $\mathrm{S}$ & A & IS & AR & $\mathrm{CV}$ \\
\hline Cambisols leptic & IV CMlp_2 & 40 & $\mathrm{~L}$ & Well & 0.1 & 0.92 & $\mathrm{~N}$ & 40.7 & 0.02 \\
\hline Cambisols calcaric & IV CMca_2 & 150 & SCL & Well & 0.1 & 0.61 & S2 & 1320.1 & 0.56 \\
\hline Cambisols chromic & III LVcr_2 & 200 & SCL & Well & 0.1 & 0.259 & S2 & 8169.7 & 3.46 \\
\hline Cambisols vertic_calcic & III CMvr_2 & 200 & SCL & Well & 0.1 & 1.02 & S2 & 4034.8 & 1.71 \\
\hline Fluvisols eutric & III FLeu_1 & 150 & SL & Moderately well & 0 & 0.32 & S1 & 3716.6 & 1.57 \\
\hline Leptosols dystric & IV LPdu_3 & 20 & $\mathrm{~L}$ & Moderately Well & 0.2 & 0.46 & $\mathrm{~N}$ & 1752.5 & 0.74 \\
\hline Leptosols lithic & V LPli_3 & 15 & $\mathrm{C}$ & Moderately Well & 0.1 & 0.58 & $\mathrm{~N}$ & 19529.5 & 8.26 \\
\hline Leptosols lithic rendzic & V LPli_2 & 10 & $\mathrm{~L}$ & Excessively/well & 0.1 & 1.41 & $\mathrm{~N}$ & 5652.0 & 2.39 \\
\hline Luvisols chromic & IV LVcr_2 & 140 & SCL & Excessively/well & 0.1 & 0.64 & S2 & 43790.8 & 18.53 \\
\hline Luvisols vertic & III LVvr_2 & 200 & $\mathrm{C}$ & Moderately/Well & 0 & 0.24 & S2 & 12903.2 & 5.46 \\
\hline Vertisols calcic \&rock. & V VRcc_1 & 165 & $\mathrm{C}$ & Poor & 3.1 & 6.36 & S3 & 1202.0 & 0.51 \\
\hline Vertisols chromic & IV VRcr_2 & 140 & $\mathrm{C}$ & Poor/poor & 0.1 & 0.1 & S3 & 54910.4 & 23.23 \\
\hline Vertisols haplic & IV VRha_1 & 180 & $\mathrm{C}$ & Moderately Well & 0.1 & 0.28 & S2 & 297.3 & 0.13 \\
\hline Not observed & & 0 & & & 0 & 0 & $\mathrm{~N}$ & 79065.9 & 33.45 \\
\hline Total & & & & & & & & 236385.4 & 100.00 \\
\hline
\end{tabular}

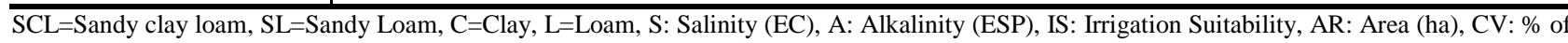
coverage

Cambisols are well, moderately well to somewhat excessively drained, shallow to deep soils. They have a moderately developed subsoil horizon, which is only in an initial stage of development. They are classified as Chromic, Calcaric, Leptic, and Vertic-calcic Cambisols occurring in the lowlands (OWWDSE, 2010).

Luvisols are soils having an Argic horizon, which has base saturation of $50 \%$ or more at least in the lower part of B horizon. Luvisols are generally well drained deep to very deep, and fine to medium textured clay to clay loam soils. Luvisols are characterized by optimum conditions for surface irrigation system in terms of all factors except that both are limited by sandy loam texture.
Vertisols are soils having a high content of clay mineral that shrinks and swell as they change water content. When wet they shrink, as they dry, forming deep cracks in horizons to a depth of at least $50 \mathrm{~cm}$ from the surface downward. They are deep to very deep and imperfectly to poorly drained soils. Vertisols classified as chromic, haplic, and calcic. Vertisols are limited by their imperfect drainage condition while the other factors are optimum for surface irrigation.

Fluvisols are major soil groups which are found adjacent to the main rivers and streams that are subject to annual flooding receiving fresh sediments from each flood. The soils are moderately deep to deep, poorly to 
imperfectly drained, medium to light textured and are stratified. The extents of fluvisols in the watershed are narrow covering only about $1.58 \%$ and are classified as eutric. Not observed soil are the soil which have a slope greater than $15 \%$ and this soil type is not suitable for surface irrigation (OWWDSE, 2010).

The result shows land in the study area with soil types that can be categorized as S1 (highly suitable), S2 (moderately suitable) and S3 (marginally suitable) classes cover an area of 3,716.62 ha, 69,761.9 ha and 56,112.30ha respectively (Table 4). Lithic Leptosol (lithic, dystric, \& lithic rendzic) and Cambisols leptic are limited by shallow soil depth $(<50 \mathrm{~cm})$ which is unfavorable for crop growth and surface irrigation method, the areas covered by soils were classified as N (not suitable class) are 105,664.0 ha including the unobserved soil
(OWWDSE,2010), land classified under N class accounts for $44.86 \%$ of the total study area.

\section{Land Cover/Use Evaluation}

Land use/cover supervised classification using SPOT5.4.3 satellite image shows that ten land cover/use classes as shown in Figure 10. The land cover/use of the study area was classified with overall accuracy of $94 \%$ and Kappa coefficient of 0.929 . The Kappa coefficient of 0.929 of the land cover classification in the study area represents a strong agreement according to Rahman et.al (2006). The lowest value "dense shrub, bush land and open shrub land" were, to some extent, misclassified because of the similarity spectral properties of dense shrub bush land and open shrub land.

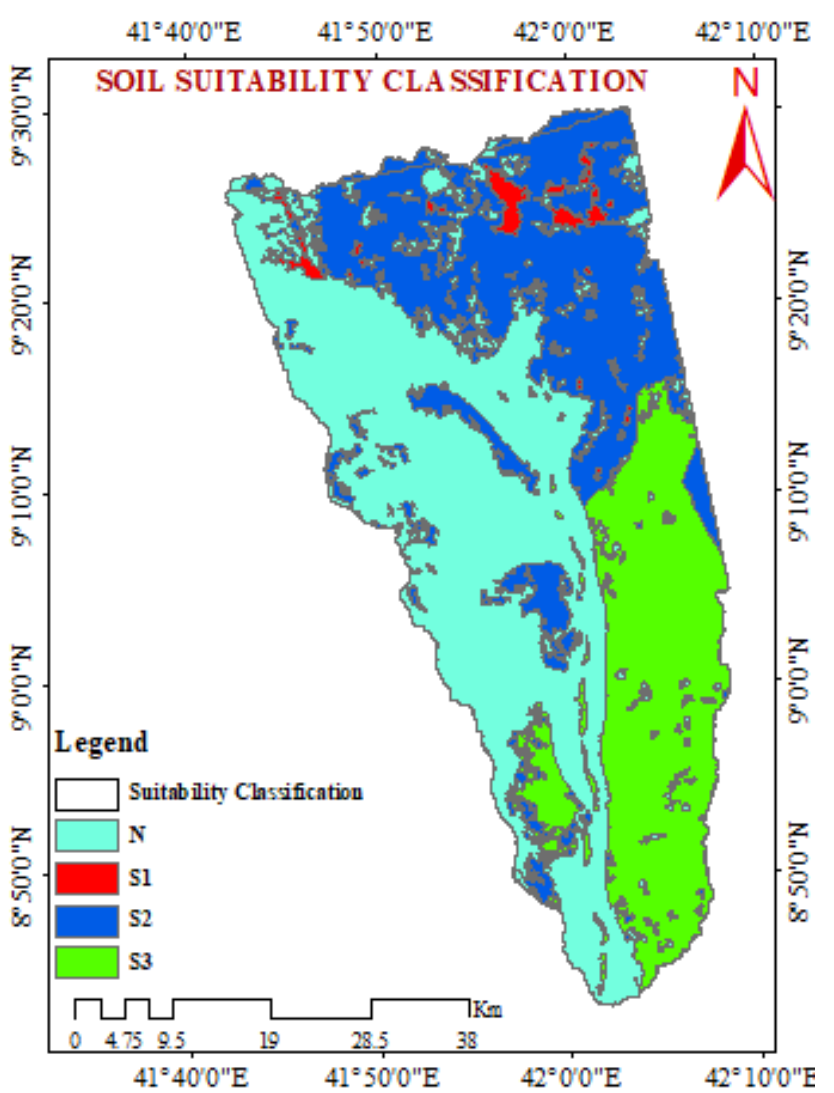

Figure 4. Soil suitability map of the study area

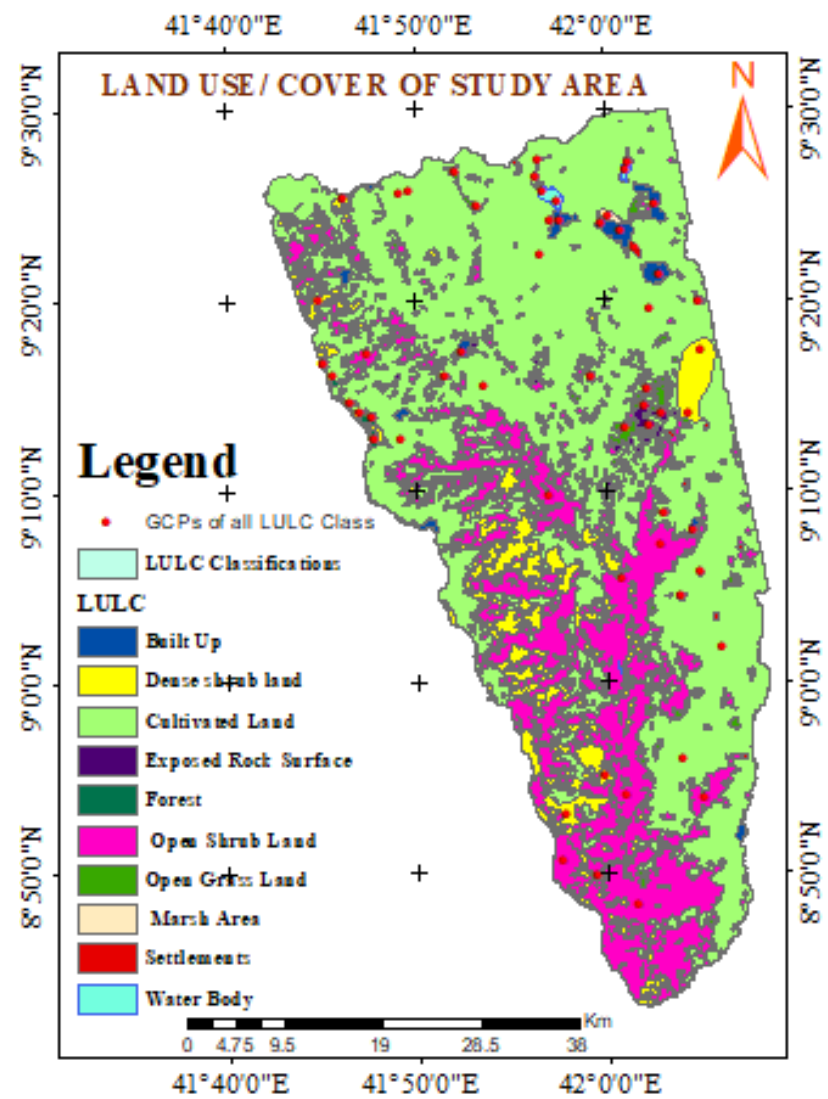

Figure 5. Land cover/use map of the study area

Table 4. Confusion matrix of SPOT 2016 LULC classification

\begin{tabular}{|c|c|c|c|c|c|c|c|c|c|c|c|c|}
\hline \multirow{2}{*}{ Classification } & \multicolumn{12}{|c|}{ Ground True(Percent) } \\
\hline & MA & WB & $\mathrm{BU}$ & $\mathrm{CL}$ & $\mathrm{BL}$ & $\mathrm{F}$ & ERSS & OSL & OGL & $S$ & $\mathrm{~T}$ & UA \\
\hline Marsh Area & 100.00 & 0.00 & 0.00 & 2.17 & 0.00 & 0.00 & 0.00 & 0.00 & 0.00 & 0.00 & 102.17 & 97.9 \\
\hline Water Body & 0.00 & 97.9 & 1.50 & 0.00 & 0.91 & 0.12 & 0.00 & 2.24 & 10.6 & 0.00 & 113.27 & 86.4 \\
\hline Built Up & 0.00 & 0.00 & 91.85 & 0.00 & 2.76 & 0.01 & 2.15 & 0.08 & 0.75 & 0.00 & 97.60 & 94.1 \\
\hline Cultivated Land & 0.00 & 0.00 & 0.00 & 92.11 & 4.30 & 0.00 & 0.00 & 0.00 & 0.00 & 0.00 & 96.41 & 95.5 \\
\hline Bushland & 0.00 & 0.00 & 0.50 & 0.00 & 78.21 & 0.00 & 0.00 & 3.00 & 0.00 & 0.00 & 81.71 & 95.7 \\
\hline Forest & 0.00 & 0.00 & 1.00 & 0.00 & 0.00 & 89.82 & 0.00 & 0.00 & 0.00 & 0.00 & 90.82 & 98.9 \\
\hline ERSS & 0.00 & 0.00 & 0.00 & 0.00 & 0.00 & 2.01 & 80.25 & 0.00 & 0.00 & 0.00 & 82.26 & 97.6 \\
\hline Open Shrub Land & 0.00 & 2.10 & 0.95 & 2.72 & 1.38 & 1.04 & 0.00 & 75.65 & 0.00 & 0.00 & 83.84 & 90.2 \\
\hline Open Grass Land & 0.00 & 0.00 & 0.20 & 0.00 & 0.00 & 0.00 & 0.00 & 1.13 & 67.65 & 0.00 & 68.98 & 98.1 \\
\hline Settlements & 0.00 & 0.00 & 0.00 & 0.00 & 10.44 & 0.00 & 0.00 & 0.00 & 0.00 & 100.00 & 110.44 & 90.5 \\
\hline Total & 100.00 & 100.00 & 96.00 & 97.00 & 98.00 & 93.00 & 82.40 & 82.10 & 79.00 & 100.00 & & \\
\hline Producer's Accuracy & 100.00 & 97.9 & 95.7 & 95.0 & 79.8 & 96.6 & 97.4 & 92.1 & 85.6 & 100.00 & $94 \% * *$ & \\
\hline
\end{tabular}

MA: Marsh Area, WB: Water Body, BU: Built Up, CL: Cultivated Land, BL: Bush land, F: Forest, OSL: Open Shrub Land, OGL: Open Grass Land, S: Settlements, T: Total, UA: User's Accuracy, Kappa Coefficient $=0.929, *$ ERSS $=$ Exposed Rock Surface with scattered shrubs, $* *$ Overall accuracy 
Land cover/use classes such as cultivated land, open grassland, and open shrub land were classified as highly suitable for irrigation with the assumption that these land cover classes can be irrigated without limitations. They cover $88.52 \%$ of the study area. Other land units such as dense shrub land and forest lands were classified as lands not suitable for irrigation. This is because according to the local culture land use reserved for these purposes can't be put under cultivation and it covers $8.58 \%$ of the study area. It is obvious that land cover classes such as Exposed rock surface with scattered shrubs, water body, settlement, buildup area, and marsh area land cover classes are restricted to use for irrigation and it covers $2.9 \%$ of the study area. Therefore, the land cover that was not suitable for surface irrigation accounts for $11.48 \%$ (Table 4).

\section{Distance from Water Source Suitability}

Based on the four classes (S1, S2, S3, and N), 93.7\% the distance from the watershed outlet are from highly to marginally suitable of the study area for the development of surface irrigation system and $6.3 \%$ is not suitably.

\section{Potential Suitable Land for Irrigation}

The final result of irrigation suitability model analysis of the watershed was classified under moderately to marginally suitable for the application of surface irrigation as shows in the Figure which covers about $10.02 \%$ and $44.6 \%$ of the total area covered in the study area respectively.

Figure 8 depicts suitability analysis for potential suitable site selection in Kurfa Chele Girawa watershed as a hierarchical structure. A scoring system of 1-3 was chosen, 3 being the most suitable and 1 less suitable for developing potentially irrigable land. The three sub watershed outlet (Maya guda, Hamaressa and Boka subwatershed) are used in pair wise comparison of water and command area availability in suitable area by considering all the four Irrigation suitability factors are equally evaluated in all sub watershed as shown in Table 5.
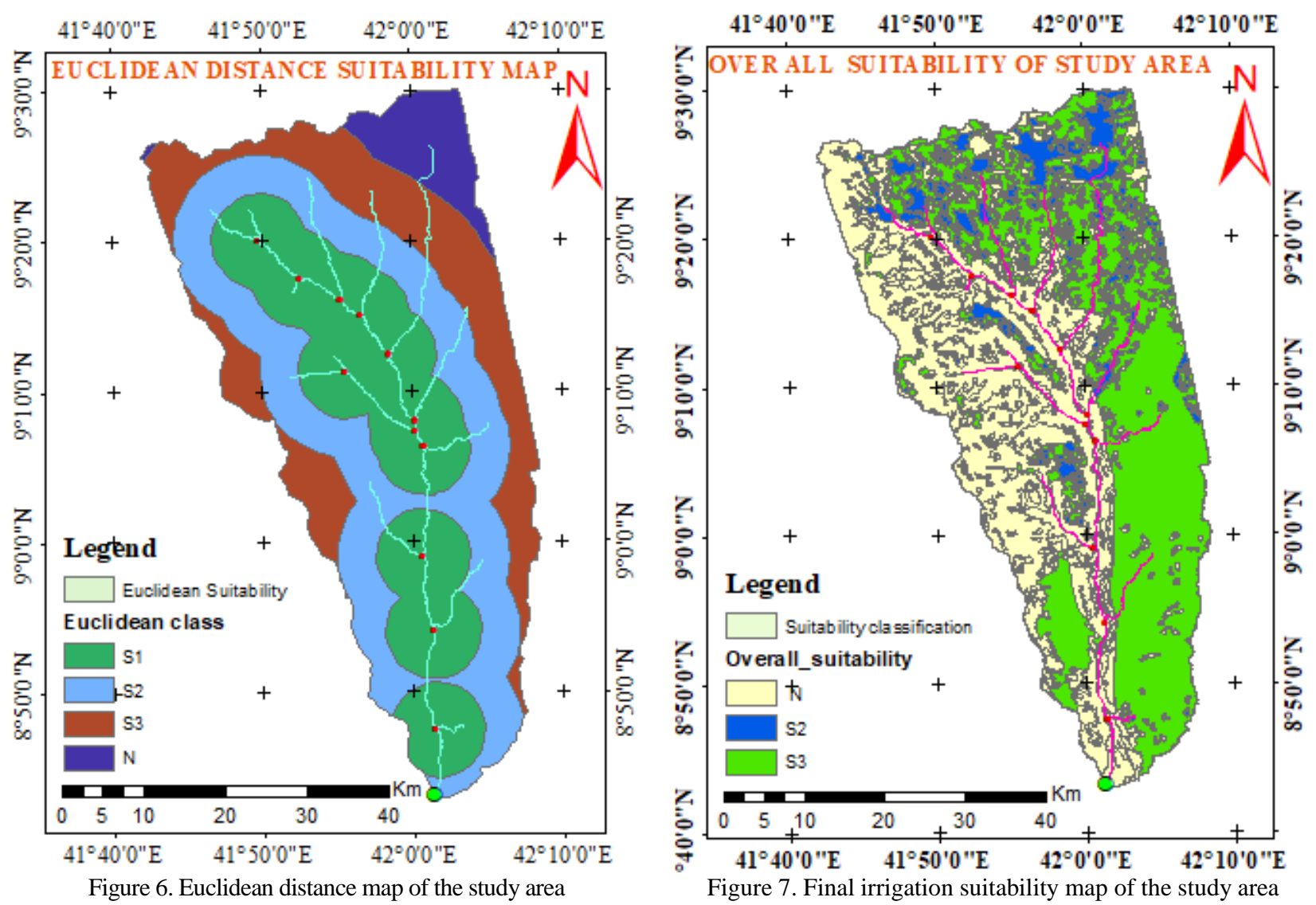

Table 5. Pair-wise comparison matrix for assessing the relative importance of different factors for surface irrigation potential in Kurfa Chale_Girawa watershed

\begin{tabular}{c|lcccc}
\hline 1 & Water availability at outlet & Hamaressa & Maya guda & Boka & Weight \\
\hline & Hamaressa(medium) & 1 & 2 & 3 & 0.61 \\
& Maya guda(low) & $1 / 2$ & 1 & $1 / 3$ & 0.21 \\
& Boka(high) & $1 / 3$ & $1 / 2$ & 1 & 0.18 \\
\hline 2 & Command area Availability & Hamaressa & Maya guda & Boka & \\
& Hamaressa(medium) & 1 & 2 & 3 & 0.61 \\
& Maya guda(high) & $1 / 2$ & 1 & $1 / 3$ & 0.21 \\
& Boka(low) & $1 / 3$ & $1 / 2$ & 1 & 0.18 \\
\hline
\end{tabular}


The identification of potential reservoir or diversion sites using the pair wise comparison matrix, Hamaressa sub watershed is chosen than the other two sub watershed in water and command area availability. The three sub watersheds are found in moderately and marginally suitability land for surface irrigation. The potential irrigable surface area identified from the total Irrigation suitability land in study area was $45.9 \%$ for future development of surface irrigation. The rest $45.4 \%$ of the area coverage classified as permanently not suitable for surface irrigation.

\section{Water Resources Assessment}

Water resources assessment relies on a full understanding of all the water flows and storages in the river basin or catchment under consideration. Prior to estimating stream-flows at the un-gauged sites from gauged sites, watersheds above both gauged and ungauged sites were characterized. Taking the watershed similarities into account, stream flows at un-gauged sites were estimated from the gauged sites by applying the runoff coefficient method.

\section{Mean Areal Rainfall of Sub-Watersheds}

Mean areal rainfall of sub-watersheds, which were used as input data to estimate stream flows in un-gauged sites, were calculated by Theissen polygon method using Arc GIS. All sub-watersheds are influenced by more than one rain gauge station's.

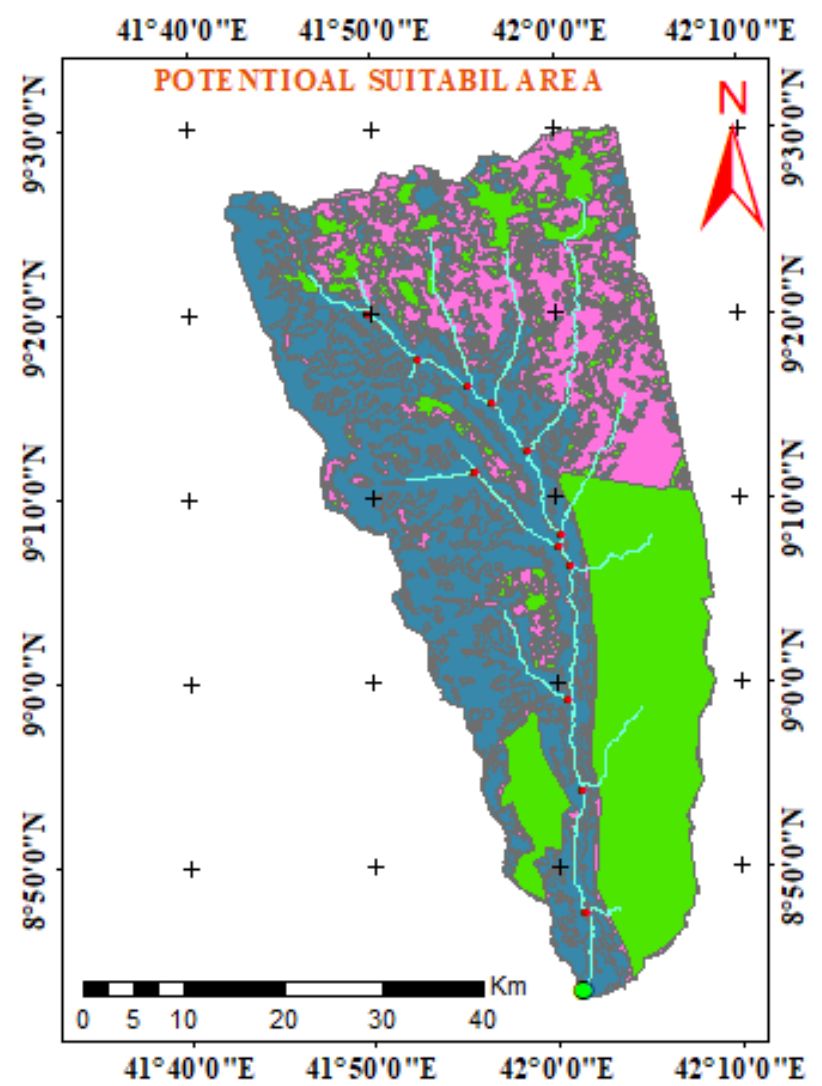

Figure 8. Potential irrigable land map of the study area

Table 6. Mean monthly stream flows of un-gauged river catchments estimated from gauged sites

\begin{tabular}{|c|c|c|c|c|c|c|c|c|c|c|c|c|c|}
\hline \multicolumn{2}{|c|}{ River Catchment Name } & \multicolumn{12}{|c|}{ Mean Monthly flows in (m3/s) } \\
\hline GR & UR & Jan & Feb & Mar & Apr & May & Jun & Jul & Aug & Sep & Oct & Nov & Dec \\
\hline \multirow{2}{*}{ Dawe } & Kersa gub. & 1.9 & 2.0 & 2.1 & 4.0 & 4.0 & 4.4 & 4.5 & 4.3 & 4.6 & 3.1 & 1.3 & 2.1 \\
\hline & Bululo & 1.3 & 1.4 & 1.4 & 2.7 & 2.7 & 3.0 & 3.1 & 3.0 & 3.2 & 2.1 & 1.8 & 1.4 \\
\hline \multirow{2}{*}{ Hamaresa } & Maya gud. & 5.4 & 4.9 & 8.3 & 9.7 & 9.7 & 9.4 & 9.2 & 8.3 & 7.9 & 7.0 & 7.4 & 6.7 \\
\hline & Maya kelo & 3.9 & 3.6 & 6.1 & 7.1 & 7.1 & 6.9 & 6.7 & 6.1 & 5.7 & 5.1 & 5.4 & 4.9 \\
\hline
\end{tabular}

GR: Gauged River, UR: Ungauged River

Table 7. Mean monthly discharges $\left(\mathrm{m}^{3} / \mathrm{s}\right)$ at the sites of interest

\begin{tabular}{l|cccccccccccc}
\hline \multicolumn{10}{c}{ Mean monthly Discharge at site of interest in $\mathrm{m}^{3} / \mathrm{s}$} \\
\hline SI & Jan & Feb & Mar & Apr & May & Jun & Jul & Aug & Sep & Oct & Nov & Dec \\
\hline Dawe-at Mudena & 1.9 & 2.0 & 2.1 & 4.0 & 4.0 & 4.4 & 4.5 & 4.3 & 4.6 & 3.1 & 2.6 & 2.1 \\
Hamaresa at Gobale & 4.1 & 3.8 & 2.3 & 7.4 & 7.4 & 7.2 & 7.1 & 6.4 & 6.0 & 5.3 & 5.7 & 5.2 \\
\hline SI Sil
\end{tabular}

SI: Site-of Interest

Table 8. Available flows of river catchments in the study area*

\begin{tabular}{l|cccccccccccc}
\hline \multirow{2}{*}{\multicolumn{1}{c|}{ River Name }} & \multicolumn{10}{c}{ Mean monthly Discharge } & at the site of interest $\mathrm{m}^{3} / \mathrm{s}$ \\
\cline { 2 - 12 } & Jan & Feb & Mar & Apr & May & Jun & Jul & Aug & Sep & Oct & Nov & Dec \\
\hline Dawe & 1.9 & 2.0 & 2.1 & 4.0 & 4.0 & 4.4 & 4.5 & 4.3 & 4.6 & 3.1 & 2.6 & 2.1 \\
Hamaresa & 4.1 & 3.8 & 2.3 & 7.4 & 7.4 & 7.2 & 7.1 & 6.4 & 6.0 & 5.3 & 5.7 & 5.2 \\
Kersa gub. & 1.9 & 2.0 & 2.1 & 4.0 & 4.0 & 4.4 & 4.5 & 4.3 & 4.6 & 3.1 & 1.3 & 2.1 \\
Bululo & 1.3 & 1.4 & 1.4 & 2.7 & 2.7 & 3.0 & 3.1 & 3.0 & 3.2 & 2.1 & 1.8 & 1.4 \\
Maya gud. & 5.4 & 4.9 & 8.3 & 9.7 & 9.7 & 9.4 & 9.2 & 8.3 & 7.9 & 7.0 & 7.4 & 6.7 \\
Maya kelo & 3.9 & 3.6 & 6.1 & 7.1 & 7.1 & 6.9 & 6.7 & 6.1 & 5.7 & 5.1 & 5.4 & 4.9 \\
Total Flows $\left(\mathrm{m}^{3} / \mathrm{s}\right)$ & 18.6 & 17.7 & 22.4 & 34.9 & 34.9 & 35.4 & 35.1 & 32.3 & 32.0 & 25.7 & 24.2 & 22.5 \\
\hline
\end{tabular}




\section{Stream Flows at Un-Gauged Sites}

The requirements suggested by Goldsmith (2000) and DFID (2004) to use the runoff coefficient method were met and thus estimated mean monthly discharges at the ungauged.

\section{Transferring Discharges to Sites Of Interest}

The discharges at the site of the interest were obtained by transferring the river discharges at the gauged site to the site of interest on the same river. The site of interest, in this case, is referring to a site closer to and above the identified potential irrigable land. Hence, the area ratio method suggested by Silesh (2001) was adopted and the results are presented in Table 7.

\section{Conclusion}

The study was conducted for Kurfa Chele-Girawa watershed which located in the Wabe Shebelle basin. The total area coverage of the watershed that obtained through watershed delineation is $237,363.1$ ha. It had been carried out to evaluate and estimate suitable irrigable land and water resource in the study area and develop the final suitability map.

The main irrigation suitability factors undertaken during the study were a slope, soil, land use/cover, and Euclidean distance. The result from the irrigation potential suitability analysis of slope, soil, Euclidean distance, and land use/cover obtained has 95.6\%, 55.14\%, 93.7\% and $88.1 \%$ respectively which ranges from highly suitable to marginal suitable for surface irrigation.

The conclusion drawn from the results obtained $54.6 \%$ and below the abstraction site was $45.9 \%$ of the study area was suitable for surface irrigation development with respect to slope, soil, Euclidean distance and land use/cover. The final suitability of the watershed shows that there was no highly suitable land for surface irrigation, the present land was in the standard of moderately and marginally suitability for surface irrigation, so addressing the specific constraint of land and management option for sustainable use. Marginally suitable land should be used under high level management.

\section{References}

Belete B. 2006. Across systems comparative assessment of Hare Community managed irrigation schemes performance. MSc thesis, Arba Minch University.
DFID. 2004. Guidelines: Predicting and minimizing sedimentation in small Dams, Zimbabweand Tanzania.

EARTHEXPLORER. 2019. https://earthexplorer.usgs.gov/

FAO. 1976. A framework for land evaluation. FAO Soils Bulletin No. 32. FAO, Rome

FAO. 1979. Land evaluation criteria for irrigation. Report of an Expert Consultation, 27 February-2 March, 1979. World Soil Resources Report No. 50. FAO Rome. 219 p.

FAO. 1990 Guidelines for soil profile description, 3rd edition. AGLS, FAO, Rome

FAO. 1991 Land use planning applications. Proceedings of the FAO Expert Consultation, 1990, Rome, Italy, 10-14 December 1990. World Soil Resources Reports 68. FAO, Rome, 206pp

FAO. 1996. An interactive multi- criteria analysis for land resource appraisal. Rome, Italy.

FAO. 1997. Irrigation potential in Africa: A basin approach FAO Land and Water Bulletin 4.

Goldsmith P. 2000. Review note on soil erosion assessment. (Unpublished project working paper), Zimbabwe and Tanzania.

IWMI. 2010. International Water Management Institute, Awulachew, Seleshi Bekele, Teklu

Jamshid Y. 2003 The integration of satellite images, GIS and CROPWAT model to investigation of water balance in irrigated area: A case study of Salmas and Tassoj plain, Iran, MSc thesis, Enscheda, Netherlands.

Janssen R, Rietveld P. 1990. Multi-criteria Analysis and GIS: An Application to Agriculture Land use in the Netherlands.

Jaruntorn BDW, Katsutoshi S. 2004. GIS-based land suitability assessment for Musa. Graduate School of Agricultural science, Ethime University.

Kebede G. 2010 A GIS-based Surface Irrigation Potential Assessment of River Catchments for Irrigation Development in Dale Woreda, Sidama Zone, SNN.

OWWDSE. 2010. Oromia Water Works Design and Supervision Enterprise; "Wabi Shebele basin Integrated land use planning", project study report, Volume I Soils, Addis Abab.

Rahman MM, Csaolovics E, Koch B, Kohl M. 2006. Interpretation of Tropical Vegetation Using Landsat ETM+ Imagery.Accessed from the Internet on Feb 15, 2010.

Saaty TL. 1988. The analytic hierarchy process. Type setters Ltd, Beccles, Suffolk

Seleshi B. 2001. Investigation of Water Resources Aimed at Multi-Objective Development with Respect to Limited Data Situations. The Case of Abaya-Chamo Basin, Ethiopia. Ph. D Thesis Technische Universitat Dresden Institute Fur Wasserbaw and Technische Hydromechanik D-01062 Dresden.

Winchell, M., Srinivasan R, Di Luzio M. and Arnold J. 2008. ArcSWAT2.Interface for SWAT 2005, User manual World Bank, 1973. Ethiopia: Agriculture sector review. Volume II, Annex 11. Report No. PA-143a. Washington. 